\title{
ASEAN CREDIT GROWTH AND ASSET PRICE RESPONSE TO GLOBAL FINANCIAL CYCLE
}

\author{
Sri Andaiyani' \\ Telisa Aulia Falianty ${ }^{2}$
}

\begin{abstract}
An upsurge and volatility of capital flows to Emerging Asian Economies indicated that there is the potential effect of global financial cycle to emerging market. It provides an overview of investor risk aversion in short term investment after financial crisis 2008. Global financial cycle could have a significant impact not only to credit growth but also asset prices, including equity prices and property prices. Rey (2015) has triggered an interesting discussion about global financial cycle. She found that there was a global financial cycle in capital flows, asset prices and credit growth. This cycle was co-moves with the VIX, a measure of uncertainty and risk aversion of the markets. Therefore, this study attempts to analyze empirically global financial cycle shocks, measured by the VIX, on credit, equity prices and property prices in ASEAN-4, namely Indonesia, Malaysia, Singapore, and Thailand. We estimate quarterly frequency data from Q1 1990 to Q2 2016 with Panel Vector Autoregressive (PVAR) approach. The result of this study showed that the response of asset markets and credit to global financial cycle shocks is negative. This result is consistent with ASEAN-4 as small open economies that remain vulnerable to the global factor. This study contributes to the literature in several ways. First, we identify not only cyclical expansions or contraction in asset markets but also the impact of global financial cycle to credit growth and asset markets in ASEAN-4 countries. Second, we also identify the pattern of cycle in ASEAN-4 countries. Third, we used PVAR approach that can capture heterogeneity.
\end{abstract}

Keywords: global financial cycle, credit cycle, asset markets, PVAR, ASEAN

\section{JEL Classifications: F30, F37, F42}

1 Sri Andaiyani is student at the Graduate School of Economics, Faculty of Economics and Business, Universitas Indonesia, Kampus Baru UI Depok 16424, Jawa Barat, Indonesia Email: andaiyanisri@gmail.com, as first author

2 Faculty of Economics and Business, Universitas Indonesia, Kampus Baru UI Depok 16424, Jawa Barat, Indonesia, Email: telisa.aulia@ ui.ac.id or telisa97fe@gmail.com, as second author and corresponding author 


\section{INTRODUCTION}

Post 97/88 Asian financial crisis Asia and 07/08 global financial crisis provide valuable lessons for policy makers and academics in developing countries. The fact that shocks to global financial condition could threaten domestic financial stability. Bruno \& Shin (2013) consider that global factors are one of the drivers of financial market fluctuations in the world. Foreign investors are likely to reduce portfolio investment in developing countries' asset markets due to increased global risks and uncertainties of monetary policy in developed countries (Adler et al., 2016)

Increased inflow of funds into developing countries after the global financial crisis is still a debate for academics. Increased inflow of funds does not only boost the real economy, but also has the potential to become a financial problem. Byrne \& Fiess (2016) state that the amount of capital inflows into developing countries is a major source of financial sector instability. Furthermore, high level of volatility suggests a high potential for reversal of fund flows in the event of a change in national and global financial conditions.

However, attention and concern over this global financial cycle are not without reason. Recently, the normalization of the unconventional monetary policy conducted by the Fed allegedly has a negative impact on the movement of capital flow to developing countries, commonly as net-capital importer countries. The increase in capital inflows is substantially related to global financial fluctuations that may change investor behavior in facing global financial risks (IMF, 2016). Since the issue of normalization was raised by the end of 2014 with the uncertainty of its implementation, fluctuations in the financial cycle have increased. Increased global uncertainty is one of the causes of fluctuations in capital flows to Emerging Market Economics (EMEs), not to mention also the flow of capital into ASEAN countries, especially Indonesia, Malaysia, Singapore and Thailand that also fluctuates (see Figure 1). The increasing foreign ownership in EMEs countries' asset market makes the countries more vulnerable to increased global risk aversion (Yildirim, 2016).

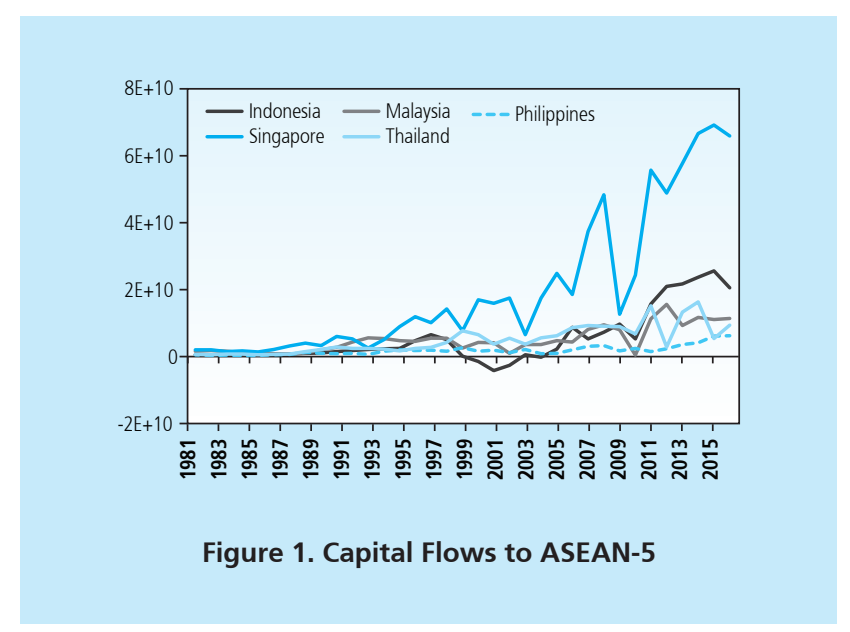


Empirical studies on the impact of both tight and loose monetary policy on the financial market of EMEs have been largely undertaken. Nevertheless, empirical research on the impact of the global financial cycle on financial market is still rare in EMEs. The research on the impact of the global financial cycle on EMEs' asset market is not detailed in analyzing the implications for each country ((Ebeke \& Kyobe, 2015);(Banerjee, Devereux, \& Lombardo, 2016)). Ebeke \& Kyobe (2015) focus on the impact of global financial risk changes on the government bond market of EMEs countries. In addition, Ciarlone, Piselli, \& Trebeschi (2009) focuses on the impact of global financial risk on the volatility of the EMEs exchange rate. Furthermore, Ananchotikul \& Zhang (2014) also focus on the impact of changes in the global financial cycle on government bond market in EMEs countries.

The movement of the global financial cycle indicates how a change of sentiment in markets considerably affects financial markets in EMEs. Figure 2 illustrates the frequency and magnitude of fluctuations in the global financial cycle projected by the Chicago Board Options Exchange Market Volatility Index (VIX). In December 2008, the VIX index reached its highest peak reflecting rising investor fears. This increase in global risks is fueling a fluctuation in the asset market thus triggering portfolio outflows from EMEs (Mishra et al, 2014).

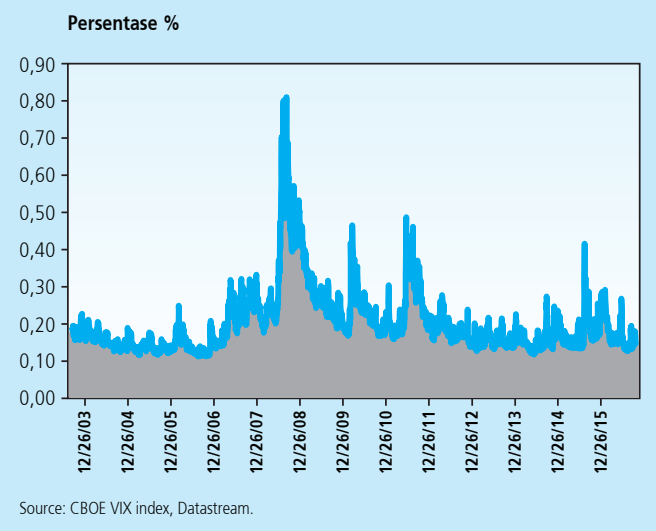

Figure 2. Global Financial Cycle Movement

A related strand of literature has pointed out an interesting discussion about the global financial cycle, in particular in relation to investors risk aversion that characterizes cross-border capital flow (Rey., 2015). The result of his research indicates that changes in the direction of the Fed's policy are the driving force behind changes in the global financial cycle that have affected the flow of funds, asset prices and credit growth. However, his research does not provide an analysis related to the patterns of financial cycles. Claessens, Kose, \& Terrones (2012), Borio \& Zhu (2012), Drehmann, Borio, \& Tsatsaronis (2012) analyze patterns and duration of 
property price cycles, stock price cycles and credit cycles, but it does not intensively provide an understanding of the causal factors and impacts of the global financial cycle. Similar research is conducted by Alamsyah, Adamanti, \& Yumanita (2014) in Indonesia, but it only focuses on the cycle duration.

Thus, this research has two major contributions. First, this research will analyze the response of asset prices and credit growth to shock on the global financial cycle. Second, this research analyzes cycle duration and pattern of each ASEAN-4 country. Based on the above problems, this research needs to be conducted to determine the pattern of global financial cycle in order to mitigate financial risk and anticipate crisis. In addition, the research on similar issues in developing countries is relatively small in number, especially ASEAN. The research conducted by Filardo, Genberg, \& Hofmann (2016) focus solely on the impact of the global financial cycle on the flow of international funds of emerging Asian countries. In particular, this research has several objectives. First, is to identify the pattern and duration of each ASEAN-4 country's financial cycle by seeing at the cycle phases and possible risks. Second, is to analyze the response of ASEAN-4 asset market to the shock of global financial cycle. The second section of this research will discuss empirical evidence used to relate between the global financial cycle and domestic financial cycle indicators. The third section explains the methodology and empirical model. The fourth section shows the result of research and discussion between variables, especially credit and asset prices response due to shock on the global financial cycle. The fifth section is the conclusion drawn from this research.

\section{LITERATURE REVIEW}

\subsection{Financial Cycle}

A decade ago, a research related to the financial cycle began to be a discussion among academics as well as policy-making. The definition of financial cycle was varied based on research focused. Various studies that explain the definition of financial cycle can not be a common reference. Generally, some studies still refer to the definition and methodology on the economic/business cycle version of the The National Bureau of Economic Research (NBER). The definition proposed by Borio \& Zhu (2012) generally represents the definition of financial cycle, namely the financial cycle is the result of interaction between perception of value and risk, behavior against risk, and financial constraints, translated as boom followed by bust. This definition is also in line with the definition proposed by $\mathrm{Ng}$ (2011) stated that financial cycle is a change in perceptions and attitudes toward financial risk over time. This definition is closely related to the recent procyclicality which is a popular term in macroprudential policy.

Financial cycle according to Anas and Ferrara (2002) is divided into two periods, namely booms period and busts period. Figure 3 shows the framework of financial cycle. The expansion period (boom) is calculated from a lowest point in the previous cycle period (Point C) to the 
next peak period (Point E). While bust period is calculated from the peak period (Point B) in the previous period to the next point of through period (Point C). Peak phase (peak of the growth cycle) shows the point with the highest deviation and positive/increasing trend series. While through phase shows the peak of decline cycle where the point with the lowest/distant deviation from the negative/decreasing trend.

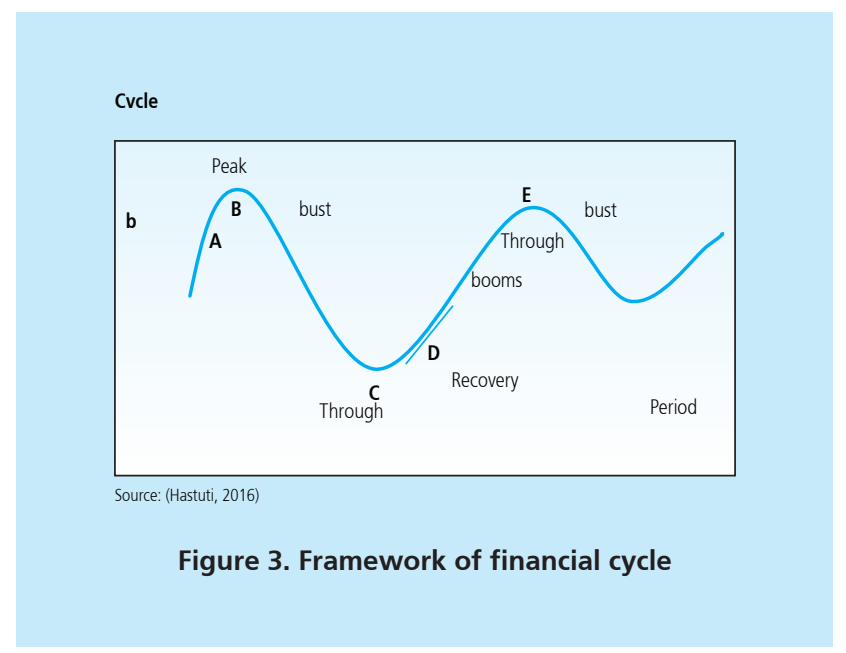

Empirical studies related to the global financial cycle believe that the variable that can drive the global financial cycle is international investor risk aversion. Some empirical studies such as Filardo et al., (2016), Rey (2015) and Miranda-agrippino et al. (2015) show the measure of risk aversion using the US stock market volatility index (VIX). This index moves along with the global financial cycle. Rey (2015) argues that there is an effect of the global financial cycle in capital flows, asset prices and credit growth driven by US interest rate policy. VIX index shows a negative and significant correlation with the flow of capital between EMEs countries (eg Bruno \& Shin (2013) and Rey (2015)).

In an annual report released by IMF (2016), key components closely related to VIX in the long term are bond yields, retail bank interest rates and bank credit. While other components closely related to VIX in the short term are stock market and exchange rate. VIX represents the expectation of global financial market volatility which in the short term is expected to have a negative sign for this variable. An increase in the VIX index raises the expectation of global financial market volatility that could reduce bank loans.

An increase in international capital flows during the global crisis has fueled economists' debate over the benefits and costs of capital mobility. On the one hand, the movement of international capital flows encourages growth over the long term. Conversely, in the short term there are challenges associated with exchange rate volatility, financial cycles and sudden capital 
reversals. Some empirical evidences shows the relationship between international capital flows, global factors, and asset prices. Rey (2015) and Miranda-agrippino et al. (2015), and Bruno \& Shin (2013) explain global factors such as the global financial cycle and changes in US monetary policy may affect asset market volatility. Miranda-agrippino et al. (2015) find that tightening US monetary policy leads to increased global risk aversion action, decline in lending between countries, and falling global asset prices. They identify a global factor that could account for most of the movement of inter-country credit flows as well as domestic credit growth. In addition, this factor may be related to change in the interest rate of the Fed.

In the globalization era and economic openness, the world's asset markets are increasingly integrated with the rapid capital inflows through credit and portfolio investment, this means that global financial factors increase the relevance for monetary policy makers in EMEs countries, especially Asian regions. In particular, the central bank of developing countries needs a special understanding of the factors that drive the measure and volatility of inflows into their countries. According to Filardo et al., (2016), global financial cycle can affect the financial condition in the EMEs countries through two paths, namely quantity and price. The impact of financial cycle spillover with quantity path can be be transmitted through capital flows. Capital inflows and outflows are the response of investors when global risks increase.

Before and after the crisis, capital flow between countries enters in the form of credit or portfolio. As global financial cycle fluctuations increase, investors tend to reduce their investment to developing countries. Capital outflows from EMEs increase so that domestic credit is reduced and asset prices fall. EMEs' concerns about the movement of capital flows can also arise through the price path, namely interest rate. Central banks of developing countries want to avoid large interest rate differentials. Short-term and long-term interest rates also play an important role in explaining the mechanism of financial cycle impact on the financial condition of EMEs countries.

The movement of domestic financial market conditions is affected by perceptions of global investors, where investors will consider the perceptions of return on investment in US relative to return on investment in developing countries. So that capital inflows are also affected by the conditions of global financial cycle. With the rising global financial risks (VIX index), it could lead to decline in lending between countries (credit), decline in asset prices. Some financial instruments, such as stocks, bonds and loans have different response in facing global financial risks. US policy interest rates (Fed Fund Rate) became one of the trigger factors of changes in the global financial cycle. Therefore, the perception of return on investment obtained in US is relative to other countries. The increasing global uncertainty affects capital flows to developing countries. Furthermore, stock price and property price as well as domestic credit financing will decline $^{3}$. Through the PVAR approach, the author can determine Cholesky's Orthogonalization which will be discussed in the next chapter.

3 Based on the framework below, the researcher can apply the transmission and sequence (order) on several financial variables before the response in some later periods. 
The high level of correlation of global factors with VIX is striking. Based on the analysis of Adrian \& Shin (2008) and Miranda-agrippino et al. (2015) proposed a structural interpretation of these factors. This can be understood as a reflection of the joint evolution of an effective market risk appetite as well as realized market volatility. In turn, the effective risk appetite of the market can be attributed empirically to the subset of financial market intermediaries whose investment strategy is well-thought out by the VaR (brokerage brokers in the US, the major European banks with significant trading operations and, more generally Banks fall into the category of "capital market" in Bankscope). Given that structural interpretation, it is not surprising that the factor empirically must be closely (negatively) correlated with VIX. The smaller risk premium strengthens the credit outburst. The measured risk is low and the balance sheet looks healthier as asset prices rise. By reducing the risk-value constraint, it creates additional space for loans and credits, and so on. This mechanism is an important positive feedback between credit creation and risk spread. This contributes to the procyclicality of credit flows and their importance in building financial fragility.

According to Lane (2013) some financial instruments such as stocks, bonds and loans have different responses to the global financial cycle. On the other hand, with the prospect of strong economic growth and higher interest rates encouraging foreign investors to channel capital into the country (Kenç, Erdem, \& Ünalmış, 2016). Thus, when all the risks to the financial stability system increase after a shock, financial market participants will reduce their assets to avoid the possibility of failure in obtaining return. Bekaert, Hoerova, \& Lo Duca (2013) analyzes the relationship of US policy interest rates and global financial measures (VIX) to US equities. The results show that the Fed's interest rate decline is followed by a decrease in the VIX index.

Banking credit can grow quickly triggered by several factors which is part of the normal phase of a business cycle, the existence of liberalization of financial sector and high capital inflows. Under normal conditions, rising domestic economy is one of driver credit growth. This is triggered by the need for good corporate investment as well as additional capacity. The high credit growth can also be triggered by liberalization in the financial sector that is generally designed for Increase the depth of the financial sector. Other contributing factors high credit growth is the existence of capital inflows. The capital inflows will increase funds of investment by banks that ultimately increase credit growth. In contrast, credit growth is triggered by excessive response financial sector more lead to excessive credit growth (Credit Boom). This condition is based on theory financial accelerator. Financial accelerator happens because of market imperfection effect such as asymmetric information as well as institutional.

Interestingly, the VIX is a powerful index of the global financial cycle, whether for flows or for returns. Rey (2015) emphasizes striking correlations and patterns, but her study cannot address causality issues. Low value of the VIX, in particular for long periods of time, are associated with a build up of the global financial cycle: more capital inflows and outflows, more credit creation, more leverage and higher asset price inflation. Moreover, a rise in the 
VIX as measure of degree of market stress, has been typically associated with the weakening in the EMEs financial cycle. Thus, this study needs to analyze the impact of the global financial cycle on the financial market through both global factors namely the global financial cycle and the US monetary policy.

\subsection{Empirical Studies}

In developing countries, empirical studies on the global financial cycle is still rare. Research on global financial cycles has been conducted based on regional data such as in Latin America, Europe, North America (Miranda-Agrippino and Rey, 2015), Emerging Asia countries such as China, Indonesia, Malaysia, Singapore and Thailand (Banerjee et al, 2016) and (Rey, 2015). Rey (2015) argues that there is a global financial cycle that affects capital flows, asset prices, and credit growth. This cycle moves along with the VIX index, as a measure of uncertainty and risk aversion. The asset market with more incoming credit streams will be more sensitive to the global financial cycle. The results of his research indicate one of the determinants of the global financial cycle is the monetary policy in developed countries, and ultimately affect the global bank debt, capital flows and credit growth.

Banerjee et al. (2016) stated that the response of asset prices and interest rates in EMEs to monetary contraction in central countries is greater than the direct response of variables in the own country. These results are reinforced by (Chudik \& Fratzscher, 2011) that EMEs are more vulnerable to global risks than shocks to US liquidity. An increase in the VIX index leads to a decrease in the returns on equity and short-term interest rates, particularly in Latin American countries that are more sensitive to global risks than in Asia. As developed countries, Europe are more sensitive to US global financial risks during the crisis.

Several studies have discussed how global financial shock can affect financial condition in Emerging Market Economies. It can be transmitted through several channels such as trade channel and credit channel. In his research, Didier et al. (2015) stated that the global export recorded strong growth to developing countries in the last decade. In addition, they have diversified production and export. More open to international trade will increase country's possibility to get affected by global financial turmoil. Similar arguments can also be transmitted through credit channels, capital flows driven by unconventional monetary policy affect capital flows to developing countries, especially for credit growth (Kenç, Erdem and Ünalmı, 2016). The argument supported by Rey (2015) that the sharp increase in credit flows are related to foreign direct investment and portfolio flows.

The current study was conducted by Tong (2017) using Panel Vector Auto-regression model (PVAR) and the US federal fund rate as a proxy for the global financial cycle. The impact of US monetary policy is transmitted through capital flows. The Fed's policy rate caused an increase in the VIX index and declined in bank risk. Banks are drawn from Bloomberg, and 
are identified based on the Global Industry Classification Standard (GICS). The findings show a negative correlation between US monetary policy and default risk of bank globally. The negative coefficients support the notion that banks take risks, rather than that their positions get compromised by adverse economic conditions. These results are consistent with Rey (2015) and Bruno and Shin (2015) who found a negative relationship between the global financial cycle and credit growth. In addition, Brana \& Prat (2016) found empirical evidence of the impact of global liquidity excess on equity prices by using threshold panel models for 17 developing countries. The excess global liquidity reflects the global financial cycle and the VIX index is used as a measure of global investor sentiment. The result shows that excess global liquidity has a positive impact on asset prices. When investor risk-averse behavior suddenly increases, for example when global financial risks increase, there will be an increase in asset prices.

Using the Panel Vector Auto-regression model (PVAR), Brana, Djigbenou and Prat (2012) found that excess global liquidity (as global financial cycle) led to an increase in output and housing prices in developing countries. However, it does not have a significant effect on asset prices and commodity prices. The findings are supported by Falianty (2016) that there is a weak correlation between capital flows and property prices for developing countries, namely Indonesia. Weak correlation of capital flows with property prices because the property market in Indonesia is highly dependent on credit as a source of financing.

Meanwhile, global financial factors can also be linked to US monetary policy conditions through risk-taking. Brana \& Prat (2016) studied the importance of global risk aversion in transmitting global financial fluctuations in the financial markets of EMEs. Excess liquidity as a result of loose monetary policy will affect the return on equity depending on risk aversion behavior of foreign investors. US monetary policy is considered a global factor that can affect domestic and foreign financial markets through risk-taking behavior. In addition, EMEs financial cycle is not only influenced by the US effect but also the China Effect. According to Rafiq (2016), this effect has strengthened since the global financial cricis. In particular, if other systemic markets outside of Asia were impacted by China, for example due to confidence effects that lead to a global risk-off episode with a rise in the VIX, spillovers from China to ASEAN could be more than twice as large. The stronger economic growth in China, through a compression in risk premia, could contribute to the procyclicality of credit flows into ASEAN.

\section{METHODOLOGY}

The method used to determine patterns and financial cycle in each country in ASEAN-4 is frequency-based filter analysis with Hodrick-Prescott filter method. This analysis follows (Drehmann et al., 2012) on analyzing the financial cycle. This method considers the possibility of changes in frequency and amplitude of the cycle during the observed period. The advantage of the frequency-based filter method is to produce a common cycle graphic, so it can be analyzed to the amplitude of financial cycle. In accordance with the objective of this research that is to 
determine the pattern and duration of financial cycle during the observation period, frequencybased filter method is the appropriate method of analysis to be used. Data used include data of ASEAN-4, namely Indonesia, Malaysia, Singapore and Thailand, with the period ranging from 1990 to $2016^{4}$. Data used as constituent candidates for the financial cycle include the variables that illustrate (i) financial limitations, namely credit, and (ii) asset prices that reflect risk perceptions, namely Stock Price Index and Residential property price Index. The period of data is in the quarterly period. In addition, this research will observe several phases of the financial cycle. Peak phase of the growth cycle shows the point with the highest deviation and increasing/positive trend series. While through phase shows the peak of declining cycle where the point with the lowest/distant deviation from negative/decreased trend.

Estimation method to be used is PVAR as has been conducted by Brana, Djigbenou, and Prat (2012) and Assenmacher-Wesche \& Gerlach (2008)5. The PVAR estimation method used in this research allows the author to reveal heterogeneity of inter-state responses to global financial shock, in contrast to the panel method commonly used in the research of global financial spillover effects on EMEs countries. This estimator does not necessarily assume that the economic structure in countries is the same (Assenmacher and Gerlach, 2008). This study employs PVAR user-based package developed by Abrigo and Love (2015) which uses GMM estimation to estimate Panel VAR. Helmert transformation is used to remove the fixed effects (i.e. the difference between each variable and its forward mean) ${ }^{6}$. It preserves the orthogonality between transformed variables and lagged regressors. Coefficients are estimated by GMM, lagged regressors being used as instruments. The empirical model in general is:

$$
\begin{aligned}
& y_{i, t}=A_{0 i}(t)+A_{i}(l) y_{t-1}+x_{i t} B+u_{i t}+e_{i t} \\
& i \in\{1,2, \ldots, N\}, t \in\left\{1,2, \ldots, T_{i}\right\}
\end{aligned}
$$

Where $y_{i, t}$ is a vector $(1 \times k)$ of the dependent variable; $x_{i t}$ is a vector $(1 \times l)$ of exogenous variable; $u_{i t}$ and $e_{i t}$ is a vector $(1 \times k)$ of the dependent variable of specific fixed-effects and error term. $y_{i, t}$ is stock price index, property price index, global financial cycle, and the Fed Fund Rate (FFR). The variables that can affect credit growth, stock prices and property prices are FFR and VIX as an indicator of global financial cycle (major control variable according to research objective $)^{7}$. The expectation of shock on global financial cycle will be negatively responded by credit to the country. This research suspects the shock on global financial cycle will be negatively responded by stock prices and property prices.

4 These 106 quarterly periods are considered capable of showing two booms periods and two bust periods of the ASEAN-4 financial cycle. The first booms period lasted from the 1990s to 1995, then the second period occurred after 2005.

5 Panel VAR has the same structure as the VAR model, in the sense that all variables are assumed to be endogenous and interdependent

6 See Abrigo and Love (2015)

7 All data in this research are in the for of natural logarithm. 
Based on equation (1), an empirical model might be constructed as follow:

$$
\begin{aligned}
& \text { Credit }_{i, t}=\alpha_{i 0}+\alpha_{11}(l) \text { Credit }_{i, t-j}+\alpha_{12}(l) P s_{i, t-j}+\alpha_{13}(l) P p_{i, t-j} \\
& +\alpha_{14}(l) F F R_{t-j}+\alpha_{15}(l) V I X_{t-j}+\beta G D P_{i t}+\gamma E X_{i t}+\delta \text { Cadev }_{i t} \\
& +\theta \text { crisis }_{t}+u_{i t}+e_{i t} \\
& P s_{i, t}=\alpha_{i 0}+\alpha_{21}(l) \text { Credit }_{i, t-j}+\alpha_{22}(l) P s_{i, t-j}+\alpha_{23}(l) P p_{i, t-j}+\alpha_{24}(l) F F R_{t-j} \\
& +\alpha_{25}(l) V_{I X}+\beta G D P_{i t}+\gamma E X_{i t}+\delta \text { Cadev }_{i t}+\theta \text { crisis }_{t}+u_{i t}+e_{i t} \\
& P p_{i, t}=\alpha_{0 i}+\alpha_{31}(l) \text { Credit }_{i, t-j}+\alpha_{32}(l) P s_{i, t-j}+\alpha_{33}(l) P p_{i, t-j}+\alpha_{34}(l) F F R_{t-j} \\
& +\alpha_{35}(l) V I X_{t-j}+\beta G D P_{i t}+\gamma E X_{i t}+\delta \text { Cadev }_{i t}+\theta \text { crisis }_{t}+u_{i t}+e_{i t}
\end{aligned}
$$

As the researches conducted by Rey (2015); Miranda-Agrippino and Rey (2014); Filardo et al (2014); Yildirim (2016), this research also uses VIX index ${ }^{8}$ as a proxy for the global financial cycle. This index is positively correlated with risk premiums of US stocks (Graham and Harvey 2012) and world's risky assets in general (Adrian and Shin 2007; Rey 2013), and is used in empirical literature as an indicator of global uncertainty (Carriere-Swallow and Cespedes, 2013). Equation 1 is estimated using GMM fixed effect (as baseline spesification. PVAR analysis implements Cholesky's orthogonalization to apply the transmission and sequence to some domestic financial variables before a response occurs in later periods. To analyze the response of one variable to a shock in another variable, we compute the impulse- response functions (IRFs). The structure of PVAR variables is arranged according to the order of Fed Fund Rate (FFR), global financial cycle (VIX), stock price (Ps), credit (Credit) and property market with exogenous variables of economic growth (GDP), exchange rate (EX) and foreign reserves (cadev) and dummy for crisis (Crisis). We included economic growth in the model similar to Filardo et al (2014). They employ cross-border credit flows to EMEs as a function of GDP growth, the VIX and the interest rate differential against the United States. The dummy variable crisis assumes the value of one for crisis period (financial crisis 1997/1998 and global financial crisis 2007/2008) and the value of zero for otherwise.

\section{RESULT AND ANALYSIS}

\subsection{Trend and Cycle of Financial Cycle}

Based on the pattern of credit cycle in Figure 4, it shows that only the cycle of credit growth in Indonesia has a cycle pattern closest to the trend in the observed period. Credit growth in Malaysia and Singapore is more fluctuated than credit growth in Indonesia and Thailand. The

8 This index is considered as a measure of uncertainty and market risk aversion. This index is calculated by Chicago Board Option Exchange (CBOE) based on the weighted average of put and call option prices over the S\&P 500 index, and a reflection of the expected volatility of stock prices index in the future (implied/expected volatility). 
highest phase of cycle occured in some periods such as during the 1990s crisis period, the highest phase of cycle occured in the first quarter of 1991. While in 1994-2000 period, the peak cycle occurred in the third quarter of 1997. This is in line with the highest credit growth of $29.9 \%$. The expansion period took place from the first quarter of 1995 to the third quarter of 1997, followed by a contraction period that lasted from 1997Q4 to its lowest point in the first quarter of 2001 which was a through phase in the period. In this phase, credit growth contracted with credit decline reaching $-32.6 \%$ due to the absence of new credit disbursement caused by the economic crisis that hit most of Asian countries, including Malaysia, Indonesia and Thailand. Furthermore, credit growth cycle was again in the contraction phase from 2007Q3 to 2008Q2, then it experienced an expansion period from 2008Q3 to its peak in 2009Q4.

The highest phase of credit cycle experienced by Indonesia occurred in 1998Q2 during the economic crisis in Asia. In that period, the highest credit growth rate was recorded at $57.2 \%$, which was considered the impact of the weakening of rupiah exchange rate. The expansion period in Indonesia began to occur in mid-1996 until 1998. Then, the expansion phase was quickly followed by a contraction phase that occurred only in a period of 4 quarters. However, the contraction period did not show a sharp and real downward trend. The real economic deterioration factor as systemic risk faced by banks was considered to be a viable factor. However,
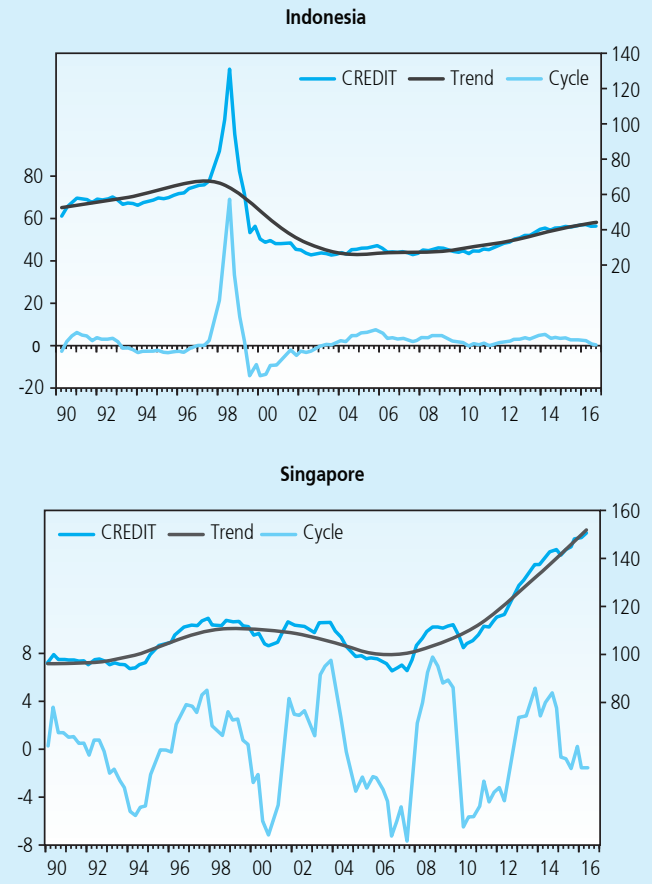
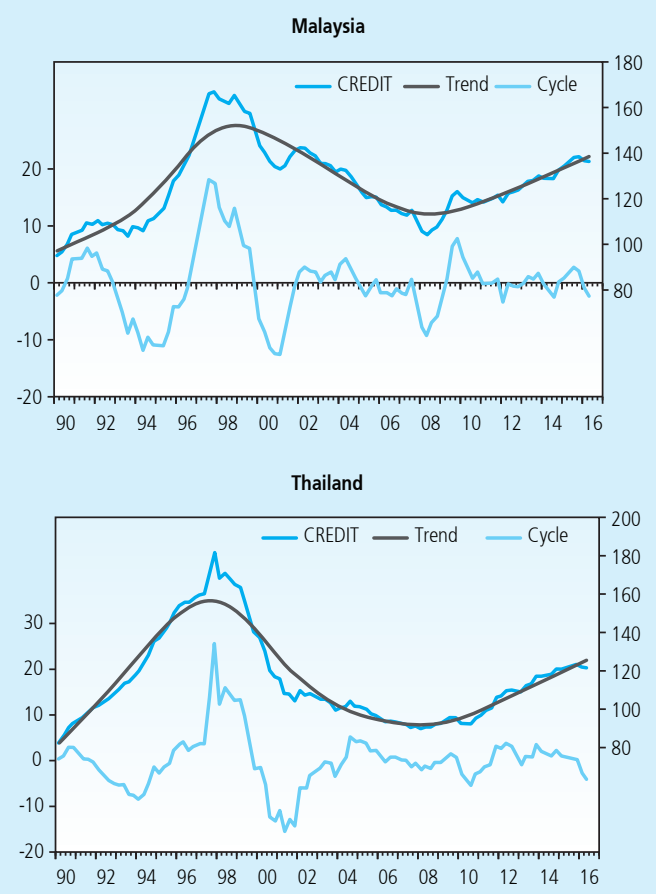
Sources: BIS

Figure 4.

Credit Cycle in ASEAN-4 Countries. LHS: Trend dan Cycle; RHS: Credit 
it seems that the global financial crisis in the early 2008 did not significantly affect the credit growth cycle in Indonesia (see Figure 4). Thus, seeing from the effect of crisis on credit growth indicates that the effect of disruption in the domestic economy is much more influential on Indonesia's financial indicators than external economic disruption.

Singapore has the most fluctuating credit growth cycle among the three other ASEAN countries. As a small country that is fully integrated with global markets in goods, services and finance, Singapore is certainly very sensitive to external shocks. There are at least three times of cycle period experienced by the country. The highest peaks during the observed period were three points, namely 1997Q4, 2003Q4, and 2008Q4. The first expansion period lasted for 14 quarters (1994Q2-1997Q4), followed by the second period from 2000Q4 to 2003Q4, and the last expansion occurred from 2007Q3- 2008Q4. The bust phase that occurred between 2004 and 2005 is suspected to have an indirect impact of shock on oil prices and technology. Monetary Authority of Singapore (MAS) said that the high global oil prices and decline in the electronics industry sector triggered the demand for Singapore's electronics exports that declined sharply. This affects the disbursement of credit to the private sector due to the decline in corporate and household income. The highest peak in 2008 was triggered by low interest rates. The fluctuating condition of Singapore's credit cycle is due to the high level of interdependence of the Singapore financial system. $65 \%$ of total banking assets are represented by branches of foreign banks. The dominance of foreign branches creates pressure on Singapore's banking liquidity.

In addition to the Asian economic crisis period and the global financial crisis, it is also identified the contraction period in 1990-1992. This happened almost simultaneously with the bubble in property prices and asset prices that occurred in Japanese economy (The lost decade). This result indicates that crisis in home-country, sources of funding for Singapore can also affect Singapore's financial cycle from expansion to contraction. In addition to investment from the United States, this country is also dominated by Japanese investment. Based on the trend and cycle of credit growth, it indicates that external factors have more significant effect than domestic economic condition factor. It is seen in the credit growth during the period of global financial crisis in Singapore which was negative, on the contrary, 97/98 Asian economic crisis showed positive credit growth.

As with Singapore, Thailand was also affected by the bubble in property prices and Japanese asset prices seen in the contraction period, the contraction period also occurred in 1990-1993. Unlike the previous three countries, the trend and amplitude of Thailand's credit growth cycle was the highest. The expansion period lasted for 13 quarters from 1994Q1 to 1997Q4, then followed by a contraction period of economic crisis from 1998Q2 to 2001 Q2. Thailand's credit growth rate was recorded as the highest (35.7\%) and the lowest (-51.00\%). It is not suprising if these two values are the most extreme among the three other countries observed. This is because Thailand is the first country to experience economic crisis in Asia before spreading to other Asian countries. In contrast to credit growth, the stock market of 
four ASEAN countries was selected to show a real contraction period at the time of 2007/2008 global financial crisis.

In addition, for stock prices in Indonesia, there is a sharp difference before and after the global financial crisis. Seeing from Figure 5, Malaysia's stock price cycle has higher effect during the Asian economic crisis, but it does not apply to Indonesia which actually has a stronger stock price cycle affected by global financial crisis than domestic finance. It can be seen from the ownership composition of Indonesian stock market recorded in C-BEST which is still dominated by foreign investors with ownership percentage of $64 \%$. Therefore, the Indonesian stock market is very vulnerable to the negative sentiment coming from global finance.
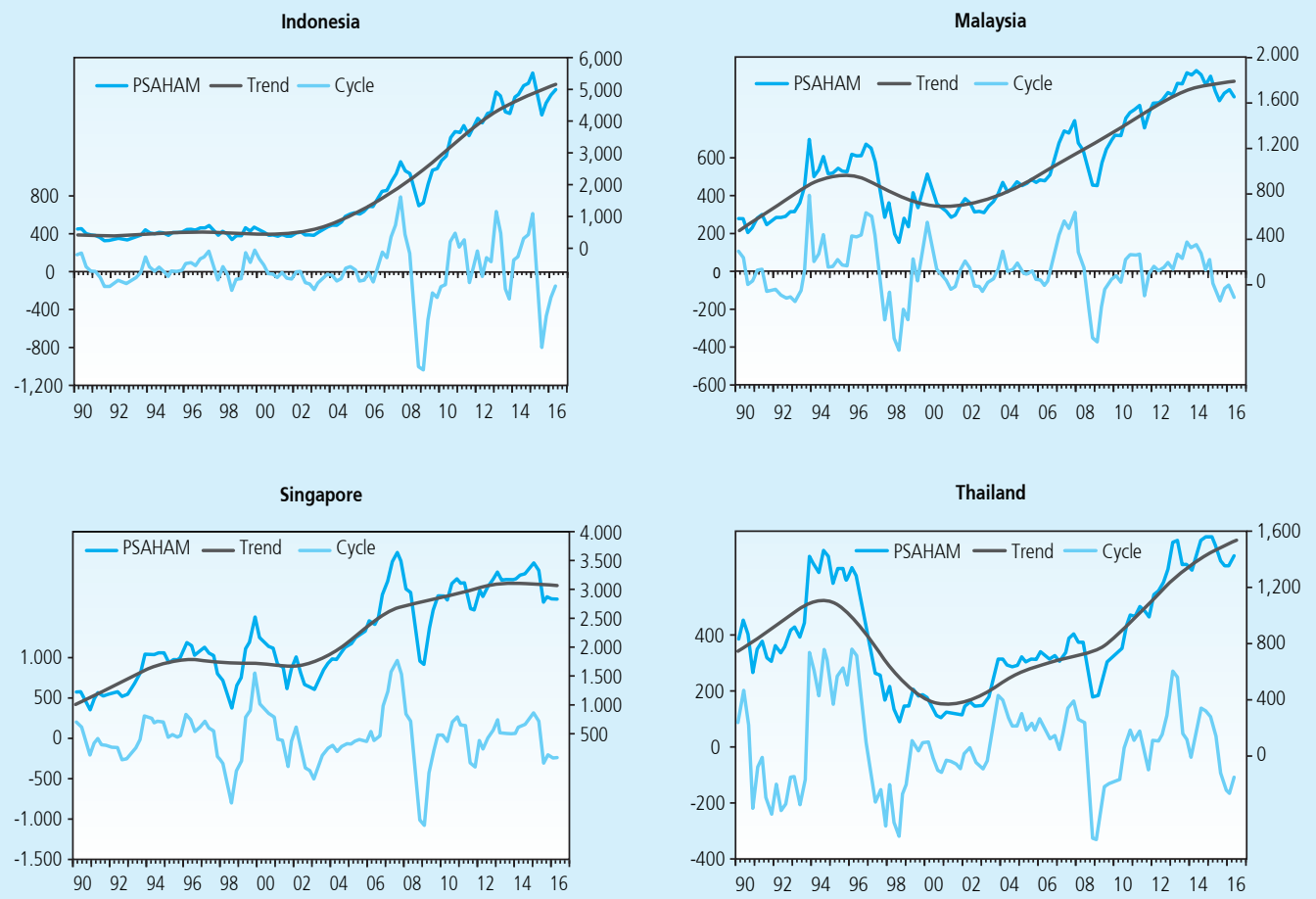

Sources: Bloomberg; LHS: Trend dan Cycle; RHS: Stock Price.

Figure 5.

Stock Cycle in ASEAN-4 Countries.

The property prices cycle in Indonesia, Malaysia and Thailand show different patterns and amplitudes over time (see Figure 6). These three countries do not show a clear and sharp repetition pattern as Singapore. During the observation period, Singapore had two lowest points (through), which was during the 97/98 Asian economic crisis and the 07/08 global financial crisis. 
Singapore's property prices peaked in 2008, before it was finally corrected in 2009 . The low interest rates are the main key to the property price boom (IMF, 2013). In addition, it has to do with an increasingly opened foreign ownership permit for property in Singapore. Although the rules of foreign ownership are very strict, but seeing Singapore's excellent development prospects, the flow of investment into the country remains enormous. Based on the research conducted by Savills Singapore, the purchases made by foreign investors reached $20 \%$ of total property transactions in Singapore in 2009. From these data, it is clear that foreigners have a substantial contribution to property development in Singapore.
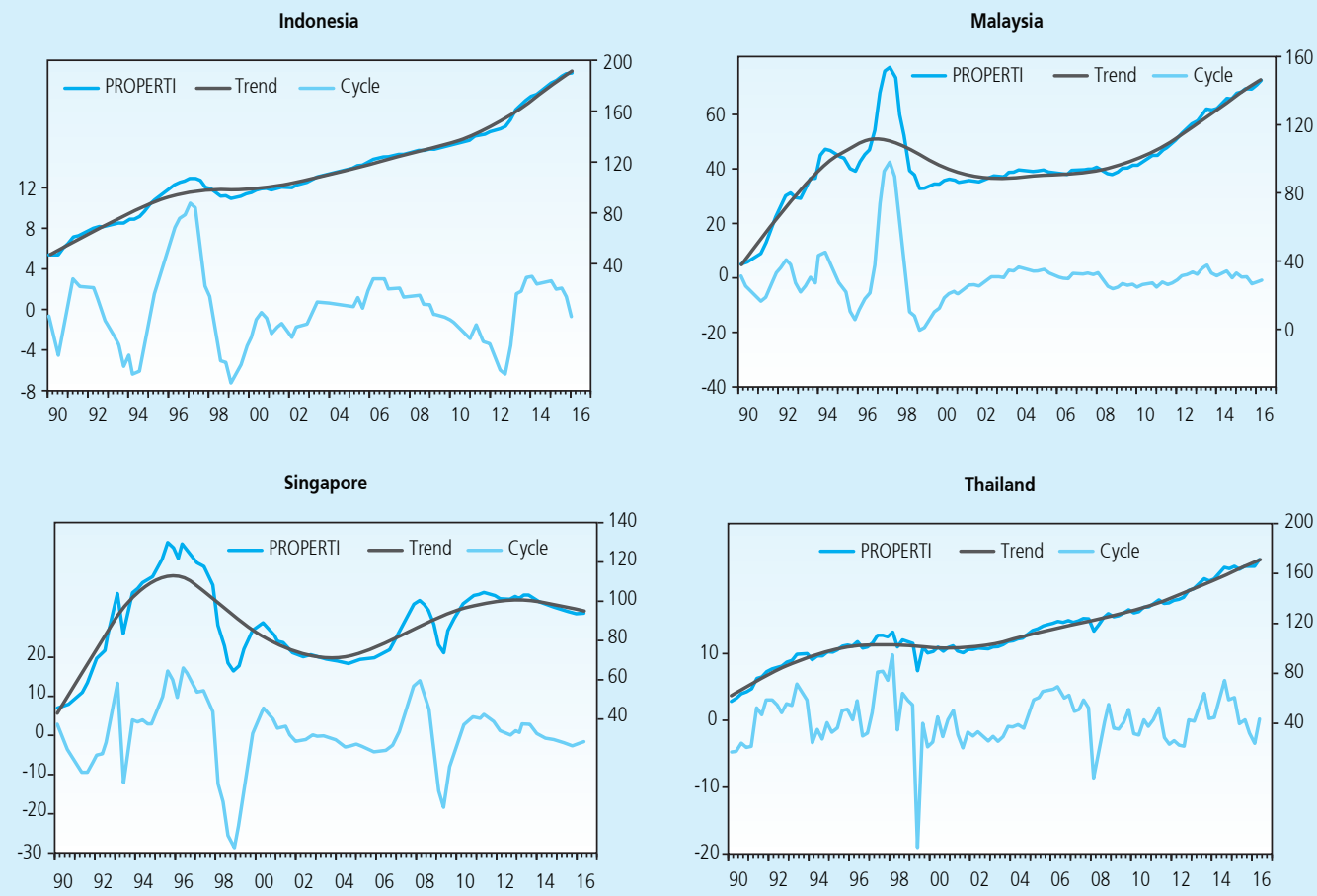

Sources: Bloomberg; LHS: Trend dan Cycle; RHS: Property Price.

Figure 6.

Property Price Cycle in ASEAN-4 Countries.

Duration of credit cycle expansion is longer than contraction trend. In pre Asian economic crisis, the expansion duration occurred in Indonesia is longer than the other three countries (34Q). This is suspected that there is an effect of deregulation finance policy package, especially related to banking. One of such policy package is the CAR and credit easing which came into force on May, 1993. The financial crisis experienced by Japan in the 1990s allegedly had an effect 
on credit decline in ASEAN-4, except Indonesia. Malaysia, Singapore and Thailand experienced their respective lowest credit points in Q2:1994, Q2:1994, Q1:1994. Unlike the three countries, Indonesia did not show the impact of the bubble of asset prices in Japan on credit.

At the time of the 2008/09 global financial crisis, the credit cycle of Indonesia and Thailand did not show a clear downward trend. The global financial crisis did not really affect the countries' credit distribution. This indicates that the movement of credit cycle of both countries is driven more by domestic factors such as expectations of slowing economic growth, domestic interest rates and price stability than global factors. Unlike the two countries, Singapore showed a very sharp decline trend. Singapore's credit cycle was highly fluctuating during the observed period. Singapore and Thailand showed a sharp contraction signal during the global financial crisis. The contraction period lasted for 15 to 21 quarters during the crisis period.

After the 97/98 economic crisis, credit cycle in Indonesia and Thailand was increasingly sloping and the duration and amplitude of the cycle was much shorter than pre crisis. Different things happened in Singapore showing the amplitude at the time of global financial crisis which was higher than at the time of the $97 / 98$ economic crisis. The high Singapore's financial integration and global finance is assumed to be the trigger factor of credit decline. While the trend and amplitude of Malaysia's credit cycle showed the existence of external effect even after post-Asian economic crisis, the credit cycle was more sloping than before. But this implies that the close relationship between Malaysia and the global, especially the United States causes Malaysia to be affected by the crisis that occurred in that period.

\begin{tabular}{|l|c|c|c|c|}
\multicolumn{1}{|c|}{ Table 1. Panel Unit Root Test } \\
\multicolumn{1}{|c|}{ Variable } & $\begin{array}{c}\text { Im, Pesaran and } \\
\text { Shin W-stat }\end{array}$ & Prob. & $\begin{array}{c}\text { ADF-Fisher } \\
\text { Chi-square }\end{array}$ & Prob. \\
Credit & -8.95517 & 0.0000 & 83.9225 & 0.0000 \\
Credit/GDP ratio & -0.74059 & 0.2295 & 22.5224 & 0.0040 \\
Stock Price & -1.36662 & 0.0859 & 14.2073 & 0.0765 \\
Property price & -3.90479 & 0.0000 & 31.8810 & 0.0000 \\
VIX & -5.49030 & 0.0000 & 46.4521 & 0.0000 \\
FFR & -6.37778 & 0.0000 & 52.8617 & 0.0000 \\
GDP & -6.27712 & 0.0000 & 56.3022 & 0.0000 \\
Exchange rate & -12.7081 & 0.0000 & 145.236 & 0.0000 \\
Balance of payment & -1.67860 & 0.0466 & 16.5373 & 0.0353 \\
\hline *stationary at level 1\%, 5\%, 10\%. & & & & \\
\end{tabular}




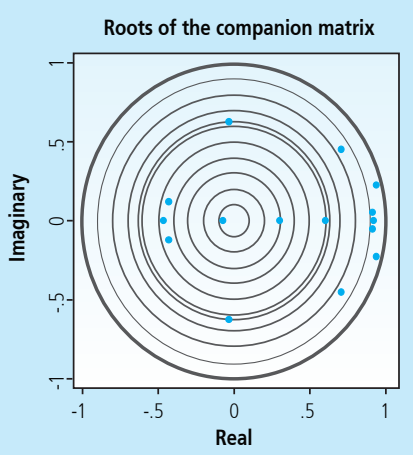

Figure 7.

Stability PVAR

Based on Im, Pesaran and Shin W-stat and ADF-Fisher Chi-square above, the test result states that all data are stationary. This research will estimate data with Panel VAR model (PVAR) by adjusting multivariate panel regression of each dependent variable with lag on the variable itself, lag on all other dependent variables, and exogenous variable. Based on three criteria of model selection by Andrews and Lu (2001) and the overall determination coefficient, panel VAR model with lag 3 is selected ${ }^{9}$. Figure 7 shows that PVAR has met the condition of stability.

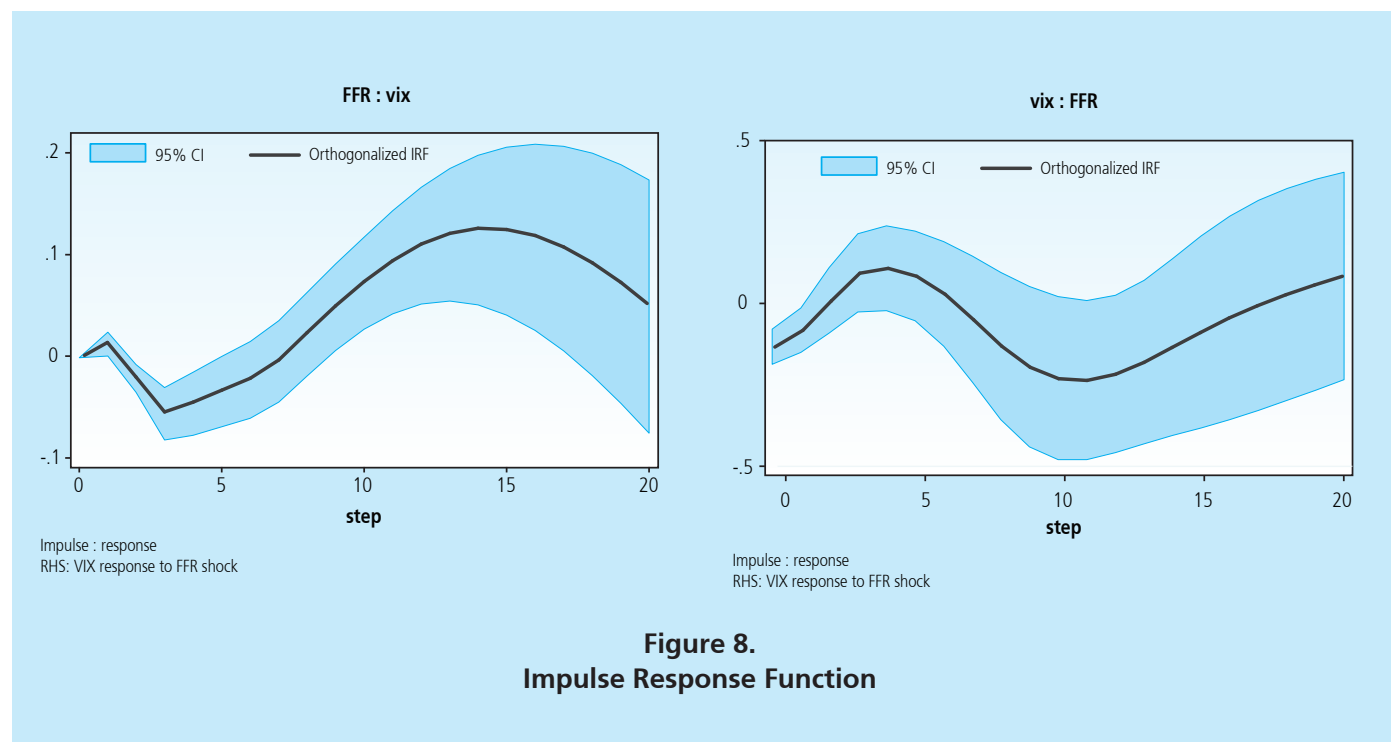

9 This lag is selected based on MBIC, MAIC and MQIC criteria. Based on the selection criteria, the research adjusts the VAR model as above by using the GMM estimation implemented by PVAR. 
The result of impulse response mapping in Figure 8 shows the response of contemporaneous changes. The result shows that changes in the global financial cycle are closely related to changes in US interest rate. US interest rates can be a trigger for VIX changes. In the 1st quarter, VIX index contemporaneously responded to the US' increasing interest rate policy (right side). The Fed's policy of increasing interest rate encourages an increase in VIX after the 7th quarter. However, in the 15th quarter onwards, the response is approaching zero indicating the VIX variable response due to the smaller FFR shock because there is an interaction with other variables over time. Figure 8 on the left shows an increase in VIX leading to a decline in the Fed's interest rate after the 5th quarter. Then, the FFR response due to shock on VIX is getting smaller and lead to convergent. Loose monetary policy lowers risk aversion and high VIX period is followed by loose monetary policy. These result suggests that an increase in VIX follows the tight monetary policy of the US central bank and loose monetary policy that occurs after VIX increases.
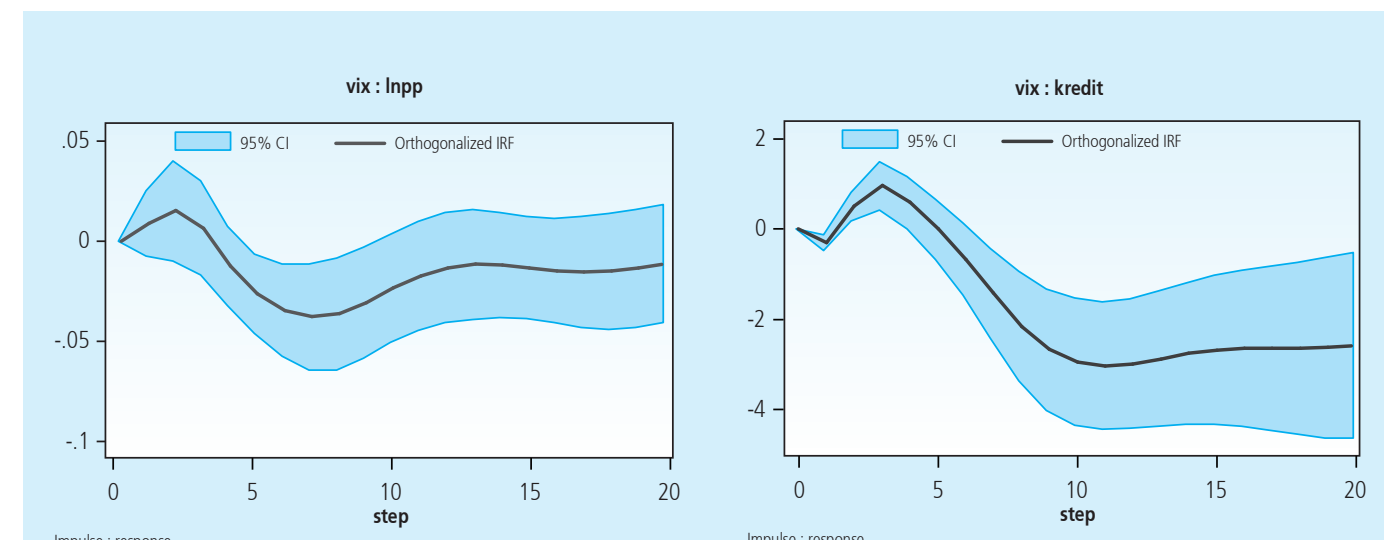

Impulse : response

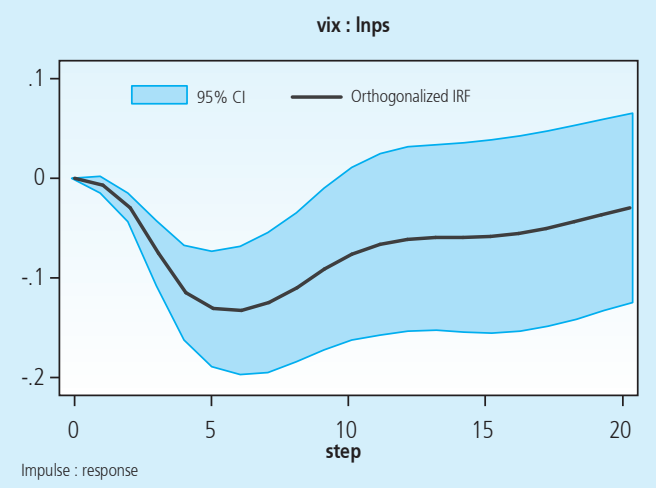

Source: Bloomberg

Figure 9.

Response Financial Cycle in ASEAN-4 to Global Financial Cycle Shock. 
Figure 9 below explains the credit growth response, stock prices and property prices against changes in US interest rates policy (as a trigger for changes in the global financial cycle). At the beginning of the period, the credit response is negative but close to zero indicating that spreading on the transmission path does not occur, but it contemporaneously has positive response to 5 th quarter. In the 6 th quarter to 10 th quarter, the credit response due to shock on VIX is negative. Furthermore, from quarter 10 onwards, the credit response on VIX shock is persistent (persisting at some level) indicating that the credit response persists. This indicates that the effect of the increasing global financial cycle is smaller in the next period. This result is consistent with the expected result that shocks in the global financial cycle will reduce credit continously. To anticipate credit decline, banks are expected to conduct forward looking reserves when the risk starts to occur (Dynamic provisions).

Similar to credit, property prices also respond to contemporaneous changes in the global financial cycle at the beginning of the period. However, this property price growth response is positive and close to zero indicating that propagation on the transmission path does not occur in the first quarter. Property prices responded negatively to the shock of the global financial cycle $(\mathrm{VIX})$ in the third quarter and beyond. The effect of the global financial cycle is approaching zero but the property price response due to shock of VIX persists even though there is a dynamic interaction between other variables over time. Thus, to anticipate the negative shock from external, financial authorities should require additional capital reserves in the property sector.

In contrast to credit and property prices, stock prices contemporaneously provide a negative response to the shock on the global financial cycle. As shown in the figure, the stock price index is very sensitive to changes in the global financial cycle. In the first quarter up to the fifth quarter, there is a negative growth in stock prices due to shock on VIX. Furthermore, in the quarter 6 onwards, the response to stock price growth is increasingly convergent toward zero, meaning that the response is smaller because there is interaction with other variables over time. Stock prices respond faster to changes in the global financial cycle because the stock is an investment that had already considered the forward looking information. Thus, stock price movement is faster than credit and property price.

Figure 10 shows when $t=1$, there is a contemporaneous but indirect response on credit, property prices and stock prices due to a shock on the Fed's interest rate. In the first quarter, ASEAN-4 domestic credit responded negatively and contemporaneously to an increase in US interest rate. Persistent credit response after the fifth quarter shows that the credit response to the Fed's interest rate shock persists over time. Increased global interest rates are commonly not responded immediately by domestic interest rate. It firstly considers the perceptions of US return relative to other countries. The response occurs to investors who expect profit through interest rate margin income. 


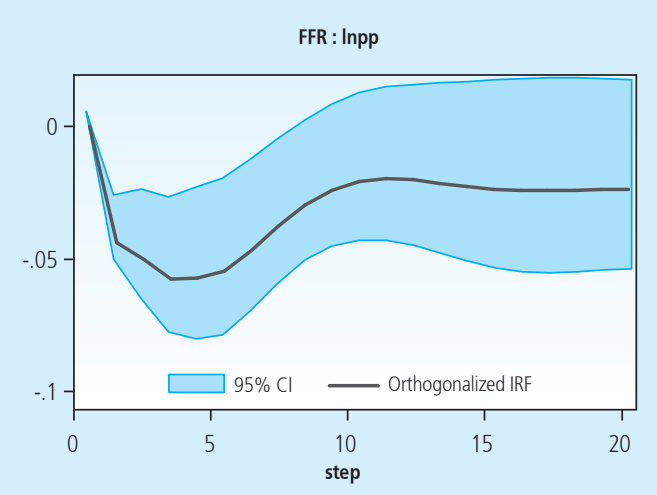

Impulse : response

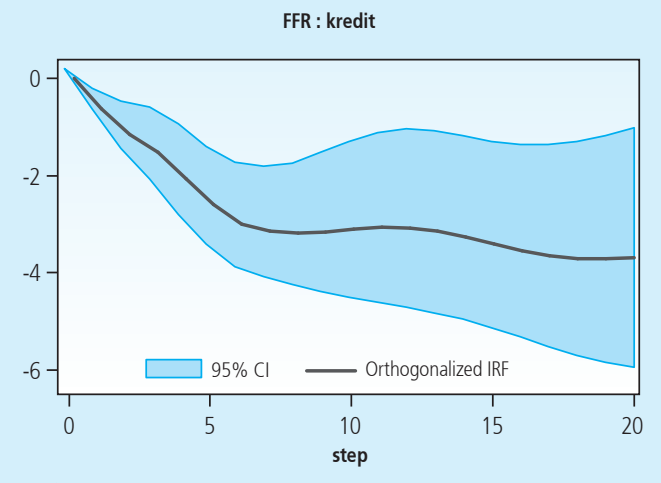

Impulse : response

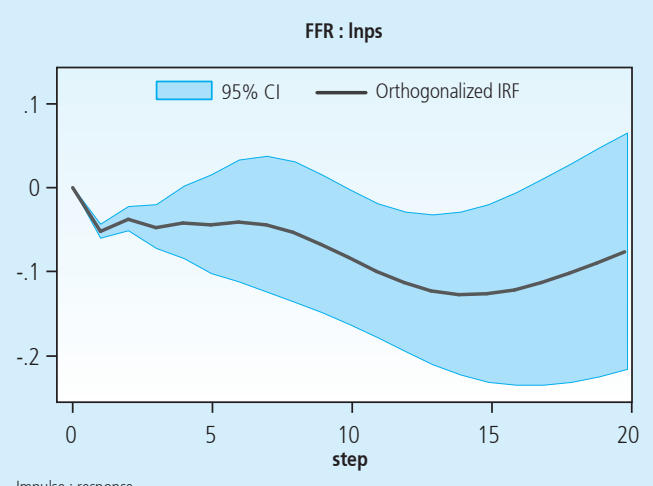

Impulse : response

Source: Bloomberg.

Figure 10.

Response Financial Cycle in ASEAN-4 to Shock of the Fed Fund Rate.

The negative property price growth response due to shock on the Fed's interest rate occurs contemporaneously through the established transition. After the 5th quarter, the property price growth response due to FFR shocks is close to zero and is getting smaller over time. However, the property price response due to FFR shocks persists despite the interaction between other variables over time. Thus, to anticipate the negative shock from the external, financial authorities should require additional capital reserves in the property sector. Similar to credit and property prices, the negative stock price growth response due to shocks on the Fed's interest rate occurs contemporaneously through the established transition. This negative stock price growth response is likely to persist at the level of 0.05 to the 9 th quarter. However, in the 10th quarter, the negative response again increased until the 15th quarter. Then, the negative stock price growth response due to the shock on the Fed's interest rate is getting smaller because there is an interaction between variables over time. 
Overall, the domestic financial vulnerability to global factors is consistent with the high level of foreign participation in the ASEAN-4 economy, with foreign portfolio capital inflows becoming the key to its spillover transmission path. From the results that have been described above, it indicates that the credit and property price responses to changes in US interest rate policy occur contemporaneously. In contrast, the response to the global financial cycle does not happen contemporaneously. However, interest rate policy and domestic liquidity condition are also important in affecting the credit cycle. In response to the shock of US policy on interest rates, stock prices also responded contemporaneously like responding to the shock of the global financial cycle. The existence of a global financial cycle is triggered by changes in US monetary policy and global risk aversion that may encourage the domestic financial condition of ASEAN-4 countries. Based on the PVAR estimation, crisis has strongly significance impact to credit growth and stock prices. Results are very similar from the HP Filter method although with less statistical significance for property price.

Table 2 shows the result of the calculation of forecast error variance decomposition (FEVD) for 20 quarters (5 years). Morana (2014) analyzed FEVD in the short term ( $<2$ years), middle term (3-5 years) and long term ( $>5$ years). FEVD shows a shock contribution to the Fed's interest rate in explaining stock prices, property prices and credits. The result shows that the Fed's interest rate shock contribution in stock price and credit is limited in the short term,

Table 2.

\begin{tabular}{|c|c|c|c|}
\hline \multicolumn{4}{|c|}{$\begin{array}{l}\text { Table } 2 . \\
\text { Variance Decomposition of the Fed Fund Rate Shock }\end{array}$} \\
\hline $\begin{array}{l}\text { Impulse } \\
\text { Variable: FFR }\end{array}$ & PP & PS & Kredit \\
\hline 0 & 0 & 0 & 0 \\
\hline 1 & .1145068 & .0004335 & .0101196 \\
\hline 2 & .0349894 & .078448 & .0050157 \\
\hline 3 & .0312541 & .0958159 & .0039649 \\
\hline 4 & .044626 & .1103606 & .0092685 \\
\hline 5 & .0555181 & .106121 & .0219767 \\
\hline 6 & .0624787 & .1029382 & .0427893 \\
\hline 7 & .0629804 & .0997904 & .0701691 \\
\hline 8 & .0590608 & .0999303 & .0960662 \\
\hline 9 & .0542358 & .10415 & .1164421 \\
\hline 10 & .0504231 & .1129227 & .1304375 \\
\hline 11 & .0477222 & .1259073 & .1399128 \\
\hline 12 & .0455707 & .1423237 & .1304375 \\
\hline 13 & .0435812 & .0435812 & .1532992 \\
\hline 14 & .0417682 & .179248 & .1600945 \\
\hline 15 & .0403118 & .1961524 & .1677756 \\
\hline 16 & .0393049 & .2103549 & .1763218 \\
\hline 17 & .0386958 & .2214978 & .1854158 \\
\hline 18 & .0383554 & .2297256 & .194577 \\
\hline 19 & .0381573 & .2354094 & .2033093 \\
\hline 20 & .0380186 & .2389673 & .2112351 \\
\hline
\end{tabular}


but it increases over time. In the medium term, FFR's role in explaining the stock price variable reaches $23 \%$. Similarly with credit, FFR's role is from $11 \%$ to $21 \%$. The role of shocks on the Fed's interest rate in explaining stock price and credit variable increases over time. While the FFR's role in explaining property price continues to decline both in the short term and long term.

Table 3. shows the result of calculation of forecast error variance decomposition (FEVD) of shock contribution to the global financial cycle (VIX) in explaining stock prices, property prices and credit. The result indicates that the contribution of the global financial cycle in property prices is very limited in both the short and medium term. VIX contribution is getting smaller as time passes. In the short term, VIX portion in stock price variable reaches $29 \%$, while the property price and credit variables reach $6 \%$ and $14 \%$, respectively. However, the role of VIX in stock prices in the long term is getting smaller. In contrast to stock prices and property prices, the role of VIX in credit variable is greater by $32 \%$ over five years.

\begin{tabular}{|c|c|c|c|}
\hline \multicolumn{4}{|c|}{$\begin{array}{c}\text { Table } 3 . \\
\text { Variance Decomposition of Global Financial Cycle }\end{array}$} \\
\hline \multirow{2}{*}{$\begin{array}{c}\text { Impulse } \\
\text { variable: VIX }\end{array}$} & \multicolumn{3}{|c|}{ Response variable and Forecast } \\
\hline & PP & PS & Kredit \\
\hline 0 & 0 & 0 & 0 \\
\hline 1 & .000258 & .2049226 & .0000113 \\
\hline 2 & .0033976 & .2485457 & .0000113 \\
\hline 3 & .004619 & .2622401 & .0388575 \\
\hline 4 & .0123642 & .2813175 & .0370796 \\
\hline 5 & .0555181 & .2905344 & .0482168 \\
\hline 6 & .0624787 & .2849697 & .0731932 \\
\hline 7 & .0629804 & .2736517 & .1067161 \\
\hline 8 & .0629804 & .2631969 & .1449336 \\
\hline 9 & .0542358 & .2546483 & .1829258 \\
\hline 10 & .0504231 & .2471036 & .2156853 \\
\hline 11 & .0477222 & .2399355 & .2412572 \\
\hline 12 & .0455707 & .2328538 & .2607047 \\
\hline 13 & .0435812 & .225792 & .2756914 \\
\hline 14 & .0417682 & .2189177 & .2874167 \\
\hline 15 & .0403118 & .2125609 & .2966357 \\
\hline 16 & .0393049 & .2070445 & .3038386 \\
\hline 17 & .0386958 & .202576 & .3093152 \\
\hline 18 & .0383554 & 1992199 & .3132401 \\
\hline 19 & .0381573 & .1969037 & .3157762 \\
\hline 20 & .0380186 & .1954446 & .3171311 \\
\hline
\end{tabular}

\section{CONCLUSION}

ASEAN-4 financial cycle represented by credit, stock prices and property prices indicates longer duration of expansion compared to duration of contraction. The amplitude of the expansion phase is higher than the amplitude of contraction phase. In addition, the amplitude of stock prices in Singapore and Indonesia is higher compared to similar indicators and other indicators 
in Thailand and Malaysia. The deepest decline period occurs in ASEAN-4 during the 97/98 Asian crisis and the global financial crisis. There is a difference of pattern and duration of stock price and credit indicating that there is no relationship between them. It is assumed that there is an effect of the ban of financing/credit or the provision of capital for equity trading, so that there is no trade-off between the two variables.

The global financial crisis does not significantly affect the credit disbursement in Indonesia and Thailand. This indicates that the movement of both credit cycles is driven more by domestic factors, such as expectation of slowing economic growth, domestic interest rates, and price stability compared to global factors. Different things happen in Singapore that show the amplitude during of global financial crisis that is higher than during the 97/98 economic crisis. The high integration between Singapore's finance and global finance is assumed to be the trigger factor for credit decline.

Indonesia experienced a sharp decline during the global financial crisis. This can be seen from the composition of Indonesia's stock ownership which is still dominated by foreign investors, so that it is still very vulnerable to negative sentiment emerging from external. Seeing from empirical result using a proven PVAR approach in stable and stationary condition, the shock on the global financial cycle is responded negatively by credit and property prices in the third period and beyond. However, stock price contemporaneously respond negatively to the increase in the global financial cycle. This is in accordance with the characteristics of forward looking measure equity investment that have previously discounted the upcoming information so that the movement is faster than credit and property prices.

Based on the results of empirical study that have been conducted, there are some policies that can be focused by policy makers or financial authorities of ASEAN countries in preventing and avoiding the negativve impact and the global financial cycle. Monetary policy and financial regulator in various countries, including ASEAN-4 have developed countercyclical framework. As a macroprudential policy is designed to mitigate the systemic risks of financial institutions due to the procyclic global financial cycle. If this is linked to an investment in an equity instrument to prevent a bubble on the asset price, the measure that can be taken by the authority is to set minimum limits on foreign investment in equity instruments and increase the percentage of local investors in share ownership.

In addition, the measure of implementing Loan to Value (LTV) on housing finance is considered appropriate to prevent the bursting of housing credit. This regulation applies when the economy is relatively not overheating and property credit growth is much higher than the general credit growth. In addition, the prudent application of capital participation activities may be more efficient and more easily implemented. The limitations of this study are twofold. First, this study is not analyzing the inter-regional relationship in ASEAN-4. Second, macroprudential policy does not include into the model. Therefore, an area for further research is to enrich the model by adding the China effect and macroprudential policy. 


\section{REFERENCES}

Abrigo, M.R. M., Love, I. (2015). Estimation of Panel Vector Autoregression in Stata: a Package of Programs. Working Paper University of Hawaii.

Adler, G., Djigbenou, M., Sosa, S., \& France, B. De. (2016). Journal of International Money Global financial shocks and foreign asset repatriation: Do local investors play a stabilizing role? Journal of International Money and Finance, 60, 8-28. https://doi.org/10.1016/j. jimonfin.2015.03.007

Adrian, T., \& Shin, H. S. (2008). Liquidity, Monetary Policy, and Financial Cycles. Current Issues in Economics and Finance. FEDERAL RESERVE BANK OF NEW, 14(1), 1-7. Retrieved from www.newyorkfed.org/research/current_issues

Alamsyah, H., Adamanti, J., \& Yumanita, D. (2014). SIKLUS KEUANGAN INDONESIA. Bank Indonesia Working Paper, WP/8/2014, 1-52.

Ananchotikul, N., \& Zhang, L. (2014). Portfolio Flows, Global Risk Aversion and Asset Prices in Emerging Markets. IMF Working Paper, WP/14/156(1), 1-27. https://doi. org/10.5089/9781498340229.001

Assenmacher-Wesche, K., \& Gerlach, S. (2008). Monetary policy, asset prices and macroeconomic conditions : a panel-VAR study. National Bank of Belgium Working Paper Series, 149(149). Retrieved from http://ideas.repec.org/p/nbb/reswpp/200810-24.html

Banerjee, R., Devereux, M. B., \& Lombardo, G. (2016). Journal of International Money Selforiented monetary policy, global financial markets and excess volatility of international capital flows. Journal of International Money and Finance, 68, 275-297. https://doi.org/10.1016/j. jimonfin.2016.02.007

Bekaert, G., Hoerova, M., \& Lo Duca, M. (2013). Risk, uncertainty and monetary policy. Journal of Monetary Economics, 60(7), 771-788. https://doi.org/10.1016/j.jmoneco.2013.06.003

Borio, C., \& Zhu, H. (2012). Capital regulation, risk-taking and monetary policy: A missing link in the transmission mechanism? Journal of Financial Stability, 8(4), 236-251. https://doi. org/10.1016/j.jfs.2011.12.003

Brana, S., \& Prat, S. (2016). The effects of global excess liquidity on emerging stock market returns : Evidence from a panel threshold model is. Economic Modelling, 52, 26-34. https:// doi.org/10.1016/j.econmod.2015.06.026

Bruno, V., \& Shin, H. S. (2013). Cross-border banking and global liquidity. Review of Economic Studies, 82(2), 535-564. https://doi.org/10.1093/restud/rdu042 
Byrne, J. P., \& Fiess, N. (2016). International capital flows to emerging markets: National and global determinants. Journal of International Money and Finance, 61, 82-100. https://doi. org/10.1016/j.jimonfin.2015.11.005

Chudik, A., \& Fratzscher, M. (2011). Identifying the global transmission of the 2007-2009 financial crisis in a GVAR model. European Economic Review. https://doi.org/10.1016/j. euroecorev.2010.12.003

Ciarlone, A., Piselli, P., \& Trebeschi, G. (2009). Emerging markets' spreads and global financial conditions. Journal of International Financial Markets, Institutions and Money, 19(2), 222-239. https://doi.org/10.1016/j.intfin.2007.11.003

Claessens, S., Kose, M. A., \& Terrones, M. E. (2012). How do business and financial cycles interact? Journal of International Economics, 87(1), 178-190. https://doi.org/10.1016/j. jinteco.2011.11.008

Drehmann, M., Borio, C., \& Tsatsaronis, K. (2012). Characterising the financial cycle : don't lose sight of the medium term! BIS Working Paper.

Ebeke, C., \& Kyobe, A. (2015). Global Financial Spillovers to Emerging Market Sovereign Bond Markets. IMF Working Paper, WP/15/141(1).

Falianty, T. (2016). Capital Flows, Macro Prudential Policy, and Property Sector. IJABER, 14(10), 6935-6958.

Filardo, A., Genberg, H., \& Hofmann, B. (2016). Monetary analysis and the global financial cycle: An Asian central bank perspective. Journal of Asian Economics, 46, 1-16. https://doi. org/10.1016/j.asieco.2016.08.002

Hastuti, F. (2016). Analisa Dampak Perubahan Siklus Keauangan Global Pada Kredit dan Harga Aset Studi Kasus Indonesia.

IMF. (2016). Global Financial Stability Report.

Kenç, T., Erdem, F. P., \& Ünalmış, İ. (2016). Resilience of emerging market economies to global financial conditions. Central Bank Review, 16(1), 1-6. https://doi.org/10.1016/j. cbrev.2016.03.002

Lane, P. R. (2013). The European Sovereign Debt Crisis. Journal of Economic Perspectives, 26(3), 49-67. https://doi.org/10.2307/41581134

Miranda-agrippino, S., Giannone, D., Gürkaynak, R., Justiniano, A., Portes, R., \& Shin, H. S. (2015). World Asset Markets and the Global Financial Cycle. NBER Working Paper, No. 21722 . 
Mishra, P., Moriyama, K., N'Diaye, P., \& Nguyen, L. (2014). The Impact of Fed Tapering Announcements on Emerging Markets. IMF Working Paper (Vol. No. 14/109). https://doi. org/10.5089/9781498361484.001

Ng, T. (2011). The Predictive Content of Financial Cycle Measures for Output Fluctuations. BIS Quarterly Review, (June), 53-65. Retrieved from http://ideas.repec.org/a/bis/bisqtr/1106g. html

Rey, H. (2015). Dilemma not Trilemma: The global Financial Cycle and Monetary Policy Independence. NBER Working Paper (Vol. 21162).

Tong, E. (2017). Research in International Business and Finance US monetary policy and global financial stability. Research in International Business and Finance, 39, 466-485. https://doi. org/10.1016/j.ribaf.2016.09.001

Yildirim, Z. (2016). Global fi nancial conditions and asset markets: Evidence from fragile emerging economies is. Economic Modelling, 57, 208-220. https://doi.org/10.1016/j. econmod.2016.04.018 